\title{
The Impact of Situational and Demographic Factors on Ethical Perceptions of Earnings Management Practices among Professionals
}

\author{
Roshan Ajward
}

\begin{abstract}
Earnings management has re-emerged as a contemporary topic particularly during and in the aftermath of the global financial crisis. In this backdrop, the two main objectives of this study were to examine whether situational factors, (i.e., nature, direction, materiality and intention of earnings management practices), and selected demographic features (i.e., gender, age, sector, employment status, tenure, educational qualifications, and professional qualifications) have an impact on the ethical perceptions of earnings management practices of professionals. For this purpose, 90 professionals from the accounting and auditing disciplines were selected and a questionnaire consisting of thirteen scenarios on earnings management administered among them. The findings of the study showed that the ethical perceptions of professionals differ according to the nature, direction, materiality and intention of the earnings manipulations involved. Further, overall, it was revealed that their ethical perceptions are not impacted by the selected demographic factors. These findings shed light on an important topic (i.e., perceptions of earnings management practices) that has not yet been examined adequately in the local context.
\end{abstract}

Keywords: earnings management, demographic factors, perceptions of professionals.

\section{Introduction}

The extant literature does not provide a global definition of the concept of "earnings management'. However, the common definition given by Ahadiat and Hefzi (2012) indicates that earnings management could be considered a manipulative intentional act with a specific objective in mind that could include regulatory, market and contracting incentives. However,

A R Ajward, $\boldsymbol{P h D}$ is a Senior Lecturer of the Department of Accounting, Faculty of Management Studies and Commerce, University of Sri Jayewardenepura. E-mail: ajward@sjp.ac.lk 


\section{NSBM Journal of Management}

Vol. 1, No. 2, July-December, 2015

research also indicates that earnings management could be considered acceptable if the earnings management practices are considered proper and reasonable for an entity that is well managed and if they provide value to shareholders (Parfet 2000). It is also well understood that ethical conduct is directly linked with ethical business practices including the avoidance of questionable earnings management practices.

In the recent financial crisis and corporate scandals, the role of the ethical conduct of professionals could be questioned and challenged especially in regard to manipulations of earnings. Copeland (2005) emphasizes that actual issues of accounting and auditing stem from the shortcomings of the character and ethical code of professionals who do not follow the correct courses of action despite the harmful consequences. However, researchers such as Jooste (2011) argue that although certain earnings management practices followed by practitioners are not illegal, they could be questionable on ethical grounds. Thus, earnings management and perceptions of professionals of such practices have reemerged as important contemporary issues.

On the other hand, research indicates that such ethical perceptions are impacted by several other factors including the demographic characteristics of individuals (Geiger \& O'Connell 1999, Deshpande 1997). However, the evidence drawn by such research is not conclusive, and in certain instances, is contradictory. For instance, in their notable study, Clikeman et al. (2001) found that gender and national origin played no significant role in the perceptions of earnings management while Deshpande (1997) found that gender and work experience did have a major influence on such perceptions. Thus, this study attempts to explore this unsettled issue in the Sri Lankan context as a contribution to the empirical and theoretical literature on the subject. The researcher also notes the lack of local studies on this subject. Most of the existing studies on the perception of earnings management have been done in developed economies, and the findings of this study shed light on both empirical and theatrical insights in a developing country. It is particularly important to examine whether opportunistic behavior is influenced by situational factors that favour a teleological theoretical viewpoint or a deontological viewpoint. Thus, the two main objectives of this research are to examine the impact of situational factors - nature, direction, materiality and intention of earnings management practices- on the perceptions of professionals in regard to earnings manipulations (hereafter referred to as situational factors), and then to examine the impact of selected demographic factors (i.e., gender, age, sector, employment status, tenure, educational and professional qualifications (hereafter referred to as demographic factors) on the ethical perceptions of professionals of earnings management practices in the Sri Lankan context. 
The Impact of Situational and Demographic Factors on Ethical Perceptions of Earnings Management Practices among Professionals

This study is organized as follows: The next section elaborates on the available literature that discusses what is meant by earnings management, the impact of situational and demographic factors on the ethical perceptions of professionals, while deriving the research hypotheses tested in this study. This is followed by the methodology adopted in testing the formulated hypotheses. Findings are presented in the next section followed by a discussion leading to conclusions and future research directions.

\section{Literature Review}

Jooste (2011) states that the practice of earnings management had been in practice for many years, and the literature provides many definitions of earnings management. Healy and Wahlen (1999) explain that earnings management takes place when the judgment of managers is used in financial reporting and in transaction structuring to manipulate the financial statements to either mislead certain stakeholders about the economic performance of the entity or to influence the outcomes of the contracts that rely on financial accounting information. Analyzing this definition, Jooste (2011) explains that there are both good and bad sides to earnings management, where misleading stakeholders is considered to be bad while making financial statements more informative is considered to be good. Belkaoui (2004) also maintains that different definitions of earnings management attempt to suggest that this concept means an intervention by management.

\section{Situational Factors and the Perception of Earnings Management}

Clikeman et al. (2000) indicate that situational factors such as nature, direction, materiality and intention of earnings management practices impact on the perceptions regarding earnings manipulations. Based on their findings, they indicate that the type (i.e., nature) of manipulation defined as accounting manipulation (alteration of existing accounting records) or operating manipulation (timing the transactions in specific periods, which is also known as real earnings management) has an impact on earnings management perceptions, with the participants indicating it was less ethical to engage in accounting manipulation as against real earnings management. Their findings indicate that although both types may be ethically questionable, the participants perceive that accounting manipulation is ethically more troubling. Next, regarding the direction of manipulation, the findings of Clikeman et al. indicate that participants considered it ethically questionable to report income as increasing as against income reducing thereby favouring the direction of earnings manipulation. Further, in terms of the materiality of the earnings manipulation involved, the findings of Clikeman et al. indicate that participants perceived it more ethically questionable if larger manipulations are made as against smaller manipulations. On the other hand, in terms of the intention 
of the manipulation, their findings indicate that participants favoured manipulations with 'good' intentions (such as managing earnings to facilitate funding of an important product development project) as against manipulative intentions (such as managing earnings to achieve a budgeted profit target of a division). These situational factors are also examined by Merchant and Rockness (1994) with similar results. The main theme underlying these empirical studies is that opportunistic behaviour overrides ethical behavior (Wesley \& Ndofor, 2013). In this respect, teleological theories such as utilitarianism and consequentialism and deontological theories make significantly different propositions on the 'correct' course of action resulting in consensus (Ferrell \& Gresham 1985, Hunt \& Vitell 1986). Based on these theoretical arguments and empirical findings, the following hypothesis (stated in its alternative form) is developed and tested for the Sri Lankan context:

H1: There is a significant difference in the perceptions of the ethical acceptability of earnings management practices based on situational factors (i.e., nature, direction, materiality and intention of earnings management practices).

\section{Demographical Factors and the Perception of Earnings Management}

Jooste (2011) argues that although not all earnings management practices could be considered as illegal, ethical questions remain. Merchant and Rockness (1994) highlight that individuals who follow these practices will be acting in an unacceptable manner if their own moral code condones such actions. Thus, engagement in earnings management practices has an ethical dimension to be considered.

The research indicates that idealists and relativists view management of earnings differently: idealists believe earnings management to be unethical while relativists consider it to be ethical (Elias, 2002; Greenfield, Jr. et al., 2007; Forsyth, 1982). Greenfield, Jr. et al. (2007) found a significant relationship between the ethical orientation of an individual and decision-making while in the same study establishing that individuals with a higher level of professional commitment are prone to less earnings management and opportunistic behavior. Thus, it is apparent that the ethical orientation of an individual is influenced by personal characteristics. Keller et al. (2007) are of the view that individual characteristics such as the gender, level of education, experience and religious beliefs influence ethical perceptions significantly. Confirming these findings, Elias (2004) also finds that gender, job title and age could be considered important factors that impact on the perception of earnings management. In respect of earnings management perceptions, the study conducted by Bruns and Merchant (1990) is considered to be the earliest (Jooste, 2011). They prepared a questionnaire covering 
13 earnings management practices. Rosenzweig and Fischer (1994) in their study indicate that professionals with more years of experience and more responsibility considered earnings management practices less severely than professionals with lesser experience and of a lower job status. Clikeman et al. (2001) examined students' perceptions and concluded that gender and national origin show no significant differences. Contrary to this finding, Deshpande (1997), examining business managers, found that ethical perspectives are different in terms of gender and work experience. Furthermore, although not directly related to earnings management, studies such as by Sweeney (1995), Cohen et.al. (1998), Eaton and Giacomino (2001) indicate that females have a higher level of moral development than their male counterparts.

An interesting study conducted by Fischer and Rosenzweig (1995) using undergraduates, practicing accountants and MBA students indicates that accounting practitioners judged manipulative accounting practices pertaining to operations to be of lesser ethical significance than others.

In the above discussion, it is noted that in terms of demographic factors, the ethical perceptions of earnings management practices of accounting professionals at best are mixed and inconclusive. Thus, the following hypothesis is formulated and tested in its alternative form pertaining to the Sri Lankan context pertaining to this study.

H2: There is a significant difference in the perceptions of the ethical acceptability of earnings management practices based on selected demographic characteristics (i.e., gender, age, sector, employment status, tenure, educational qualifications, and professional qualifications).

The next section discusses the research methodology used in testing the above hypotheses.

\section{Research Methodology}

This section elaborates on the research approach, the population and sample, the survey instrument, and the analysis strategy. 
NSBM Journal of Management

Vol. 1, No. 2, July-December, 2015

\section{Research Approach, Population and Sample}

For the purpose of this research, a positivistic research paradigm with a quantitative approach was used, which is deemed appropriate for achieving the research objectives and is based on the extant literature (Clikeman et al., 2000; Bruns and Merchant, 1990; Elias, 2002; Kaplan, 2001; Clikeman and Henning, 2000).

The population of this study constituted working professionals in Sri Lanka with professional or/and academic qualifications in accounting or/and finance and employed in the accounting and auditing fields. Based on a random sampling strategy, 100 accounting professionals working in the audit and non-audit sectors were given the questionnaires and 90 completed questionnaires were finally selected for the purpose of analysis.

\section{The Survey Instrument}

As explained above, the survey instrument used in this study was a questionnaire consisting of two sections. The first section consisted of questions on demographic factors of gender, age, industry sector, employment status, tenure, educational qualifications and professional qualifications. The second section contained thirteen earnings management scenarios adopted from Clikeman et al. (2000). The scenarios were originally developed by Bruns and Merchant (1990) and subsequently used by Merchant and Rockness (1994) and Fischer and Rosenzweig (1995) to study the perceptions of accountants of the ethics involved in earnings management.

These scenarios contain earnings management practices and the respondents were expected to rate them in terms of the severity of ethical acceptability ranging from ethical practice to totally unethical practice. Accordingly, the professionals responded to each scenario by utilizing a 5-point Likert scale ranging from 1 for 'ethical' to 5 for 'totally unethical'. It should be noted that higher scores reflect higher degrees of ethical unacceptability. The questionnaire was refined on the basis of expert comments received from two experts in the field and pilot testing.

\section{Analysis Strategy}

As the analytical strategy for examining both the influence of situational factors (i.e., nature, direction, materiality and intention of earnings management practices) and demographic factors (i.e., gender, age, sector, employment status, tenure, educational qualifications, and professional qualifications) on the ethical perceptions of earnings management of 
The Impact of Situational and Demographic Factors on Ethical Perceptions of Earnings Management Practices among Professionals

professionals in the accounting discipline, independent sample t-tests and One-way ANOVA analysis, which is based on the dominant research strategy used in the extant literature (Clikeman et al., 2000; Merchant \& Rockness, 1994), were used.

Furthermore, the non-parametric versions of these tests, i.e., Mann Whitney U-test and Kruskal Wallis test, were used as additional robustness tests.

\section{Analysis and Results}

This section elaborates on the sample characteristics, results of the analysis of earnings management scenarios, and the findings in respect of the impact of situational and demographic factors on earnings management.

\section{Sample Characteristics}

The sample characteristics pertaining to the sample are given in Table 1. It is observed that $53 \%$ of the professionals were males while $47 \%$ were females, the majority of whom were in the age range of 20-30 years. The professionals ranged in age from 23 to 58 years with a median age of 28 and a mean age of 30.37 years (not tabulated).

Among the professionals 55.6\% were from the non-audit sector and 40\% from the audit sector. The sample consisted of mostly middle level managers amounting to $49 \%$ of the 90 professionals selected; on the other hand, top level managers amounted to $15.6 \%$, the lower level managers to $23.3 \%$, and operational level managers to $21.1 \%$ of the total sample. 
NSBM Journal of Management

Vol. 1, No. 2, July - December, 2015

Table 1: Descriptive Statistics

\begin{tabular}{|c|c|c|c|}
\hline Demographic Variables & Categories & $\mathbf{N}$ & $\%$ \\
\hline \multirow[t]{3}{*}{ 1. Gender } & Male & 48 & 53.3 \\
\hline & Female & 42 & 46.7 \\
\hline & Total & 90 & 100.0 \\
\hline \multirow[t]{5}{*}{ 2. Age } & 20-30 years & 65 & 72.2 \\
\hline & $31-40$ years & 15 & 16.7 \\
\hline & $41-50$ years & 6 & 6.7 \\
\hline & 51-60years & 4 & 4.4 \\
\hline & Total & 90 & 100.0 \\
\hline \multirow[t]{4}{*}{ 3. Sector } & Audit & 36 & 40.0 \\
\hline & Non-audit & 50 & 55.6 \\
\hline & Other & 4 & 4.4 \\
\hline & Total & 90 & 100.0 \\
\hline \multirow[t]{5}{*}{ 4. Employment Status } & Top level Management & 14 & 15.6 \\
\hline & Middle level Management & 36 & 40.0 \\
\hline & Lower level Management & 21 & 23.3 \\
\hline & Operational level staff & 19 & 21.1 \\
\hline & Total & 90 & 100.0 \\
\hline \multirow[t]{6}{*}{ 5. Tenure } & $<=2$ years & 30 & 39.5 \\
\hline & $3-5$ years & 23 & 30.3 \\
\hline & $6-8$ years & 9 & 11.8 \\
\hline & $9-15$ years & 4 & 5.3 \\
\hline & $>=16$ years & 10 & 13.2 \\
\hline & Total & 76 & 100.0 \\
\hline \multirow[t]{7}{*}{ 6. Educational Qualification } & General Certificate of Education (Ordinary Level) & 0 & 0 \\
\hline & General Certificate of Education (Advanced Level) & 15 & 16.7 \\
\hline & Diploma in Accounting/Finance & 16 & 17.8 \\
\hline & First Degree in Accounting/ Finance & 50 & 55.6 \\
\hline & Postgraduate diploma & 7 & 7.8 \\
\hline & $\mathrm{PhD}$ & 2 & 2.2 \\
\hline & Total & 90 & 100.0 \\
\hline \multirow{8}{*}{$\begin{array}{l}\text { 7. Professional } \\
\text { qualifications* }\end{array}$} & No Professional Qualifications & 1 & 1.1 \\
\hline & CMA & 4 & 4.4 \\
\hline & CA Sri Lanka & 50 & 55.6 \\
\hline & CIMA & 13 & 14.4 \\
\hline & $\mathrm{ACCA}$ & 3 & 3.3 \\
\hline & Banking & 5 & 5.6 \\
\hline & Multiple Qualifications & 14 & 15.6 \\
\hline & Total & 90 & 100.0 \\
\hline
\end{tabular}

*CMA: The Certified Management Accountants of Sri Lanka; CA Sri Lanka: The Institute of Chartered Accountants of Sri Lanka; CIMA: The Chartered Institute of Management Accountants; ACCA: The Association of Chartered Certified Accountants and Banking: Banking examinations conducted by the Institute of Bankers in Sri Lanka.

Source: Constructed by author 
The Impact of Situational and Demographic Factors on Ethical Perceptions of Earnings Management Practices among Professionals

In terms of tenure, the majority of professionals had less than two years after their first academic/ professional qualification (39.5\%). The majority $(55.6 \%)$ of the respondents had a first degree in Accounting or Finance, while 17.8\% had a diploma in Accounting or Finance.

The majority of professionals had a part or full professional qualification (i.e., at least had completed the second stage of the qualification) from the Institute of Chartered Accountants of Sri Lanka (CA Sri Lanka), which as a percentage was 55.6\% and most of them were fully qualified members (not tabulated). Also, 15.6\% of the sample had at least two professional qualifications and $14.4 \%$ of members had completed at least the second stage of the CIMA qualification.

\section{Analysis of Earnings Management Scenarios}

The section on research methodology stated that the questionnaire consisted of 13 scenarios that contained different earnings management scenarios. The mean (mean) and standard deviation (SD) values of the responses obtained for these scenarios are presented in Table 2.

Scenario $7 \mathrm{~b}$ (work done but not invoiced with the value of Rs. 500,000) had the highest mean value of 3.7 (between a minor infraction to serious interaction) while the lowest mean value 1.91 (i.e., a questionable practice) was observed for Scenario 1 (advancement of a painting job to the current period with the value of Rs. 150,000). It is noted that the responses for Scenario $4 \mathrm{~b}$ had the lowest agreement among the participants (SD: 1.174), while Scenario 2a had the highest agreement among the participants (SD: .842). 
NSBM Journal of Management

Vol. 1, No. 2, July-December, 2015

Table 2: Mean Responses to Earnings Management Scenarios

Scenarios
1. Advancement of the painting of the headquarters building in
2012 that is due for 2013. (Rs. 150,000)
2a. The expenses were postponed from February and March unti
April in order to make the first quarter target. (Rs. 150,000)
(Rs. 150,000)

$2 \mathrm{~b}$. The expenses were postponed from November and December until January in order to make the annual target. (Rs. 150,000)

3. The General Manager [GM] ordered that office supplies be recorded after the year end. (Rs. 3000)

4a. The GM decided to implement a sales programme offering liberal payment terms to secure sales in advance.

$4 \mathrm{~b}$. The GM ordered the manufacturing sector to work overtime in December in order to ship everything by the end of the year.

4c. The GM sold some excess assets and realized a profit of Rs 40,000 .

5a. The GM ordered his controller to prepay some expenses and book them in 2013 instead of 2012. (Rs. 60,000)

5b. The GM ordered his Controller to develop a rationale for increasing the reserves for inventory obsolescence although being confident that they could be sold at the full price at a later date. (Rs. 700,000)

6a. The GM ordered the reduction of the reserves for inventory obsolescence to facilitate the continuance of some product development projects that might have been delayed due to budget constraints. (Rs. 210,000)

$6 \mathrm{~b}$. The GM ordered the reduction of the reserves for inventory obsolescence to facilitate meeting budgeted profit targets. (Rs. 210,000)

7a. The GM called a consultancy firm partner and asked for a postponement to the next year on sending the payment invoice for the work done this year. (Rs 30,000)

7b. The GM called a consultancy firm partner and asked for a postponement to the next year on sending the payment invoice for the work done this year. (Rs 500,000)

\begin{tabular}{|c|c|c|}
\hline $\mathbf{N}$ & Mean & SD \\
\hline 90 & 1.91 & .870 \\
\hline 90 & 2.86 & .842 \\
\hline 90 & 2.97 & .988 \\
\hline 90 & 2.81 & 1.080 \\
\hline 90 & 2.84 & 1.070 \\
\hline 90 & 2.24 & 1.174 \\
\hline 90 & 2.20 & 1.073 \\
\hline 90 & 3.03 & 1.033 \\
\hline 90 & 3.51 & .915 \\
\hline 90 & 2.58 & .971 \\
\hline 90 & 3.06 & .998 \\
\hline 90 & 2.76 & .987 \\
\hline 90 & 3.70 & .905 \\
\hline
\end{tabular}

$*_{p}<.10 ; * * p<.05 ; * * * p<.01$

Source: Author's construction 
The Impact of Situational and Demographic Factors on Ethical Perceptions of Earnings Management Practices among Professionals

\section{The Impact of Situational Factors on Perceptions of Earnings Management}

This section presents the results of the t-test that examined the differences arising from selected situational factors (i.e., nature, direction, materiality and intention of earnings management practices) in the earnings management perceptions of accounting professionals.

\section{Type of Manipulation}

As indicated in the literature survey, Clikeman et al. (2000) state that earnings could be managed either by adjusting accounting records (manipulative accounting) or by advancing or postponing real activities (manipulating operations), and explain that manipulative accounting is considered to be comparatively the more severe ethical violation. Scenarios 3 , 5a, 5b, 6a, 6b, 7a and 7b are accounting manipulations while Scenarios 1, 2a, 2b, 4a, 4b and $4 \mathrm{c}$ are operating manipulations. The mean values of the responses of these two categories of scenarios (i.e., accounting manipulations and operating manipulations) are depicted in Table 3 together with the t-test results that show whether the perceptions of the accounting professionals differ statistically significantly between these two categories.

Table 3: Accounting Manipulation and Operating Manipulation

\begin{tabular}{llllc}
\hline Manipulation & N & Mean & SD & Mean Difference \\
\hline Accounting manipulations & 90 & 3.073 & .508 & \multirow{2}{*}{$0.206^{* * *}$} \\
Operating manipulations & 90 & 2.867 & .598 & \\
\hline
\end{tabular}

$* p<.10 ; * * p<.05 ; * * * p<.01$

Source: Author's construction

Based on the paired sample t-test, there is a statistically significant difference $(\mathrm{p}<.01)$ between the professionals' perception of accounting manipulations and operating manipulations; the professionals consider that comparatively accounting manipulations are more serious ethical violations. This finding is consistent with the findings of Clikeman et al. (2000) and Merchant and Rockness (1994).

\section{Direction of Manipulation}

In regard to the direction of the manipulation, Clikeman et al. (2000) explain that Scenarios 1 and $2 b$ are quite equal except that Scenario 1 reduces the present period income whereas Scenario $2 b$ involves increasing such income. 
NSBM Journal of Management

Vol. 1, No. 2, July-December, 2015

Table 4: Increasing and Decreasing Current Earnings

\begin{tabular}{lllll}
\hline Manipulation & N & Mean & SD & Mean Difference \\
\hline Reducing the current income (Scenario 1) & 90 & 1.810 & .086 & $-1.100^{* * *}$ \\
Increasing the current income (Scenario 2b) & 90 & 2.910 & .114 & \\
\hline
\end{tabular}

$* p<.10 ; * * p<.05 ; * * * p<.01$

Source: Author's construction

The results of the paired-sample t-test shown in Table 4 indicates that the mean difference between the responses for Scenario 1 and $2 \mathrm{~b}$ are statistically significantly different, and the professionals perceive that increasing current income is more objectionable than reducing the current income, which is also consistent with the findings of Clikeman et al. (2000).

\section{Materiality of Manipulation}

The result of the paired sample t-test that compares the professionals' perception of the postponement of an expense that is material and not so material is shown in Table 5, and the result indicates that there is a statistically significant difference between them. Consistent with the findings of Clikeman et al. (2000), the findings in Table 5 indicate that professionals perceive the material postponement of recording a liability to be comparatively a more serious ethical issue.

Table 5: Materiality of Earnings Manipulation

\begin{tabular}{lcccc}
\hline Manipulation & N & Mean & SD & Mean Difference \\
\hline $\begin{array}{l}\text { Postponement of a not so material payment } \\
\text { Rs. 30,000 (Scenario 7a) }\end{array}$ & 90 & 2.760 & .987 & \\
$\begin{array}{l}\text { Postponement of a material payment Rs. } \\
500,000 \text { (Scenario 7b) }\end{array}$ & 90 & 3.720 & .862 & $-0.960 * * *$ \\
\hline$* p<.10 ; * * p<.05 ; * * * p<.01$ & & & \\
\end{tabular}

Source: Author's construction

\section{Motives of Earnings Manipulation}

It is noted that Scenarios $6 \mathrm{a}$ and $6 \mathrm{~b}$ are quite similar except for the intention of the professionals in managing earnings. The paired sample t-test results depicted in Table 6 indicate that when the manipulation involves good motives the professionals perceive that it is comparatively ethically acceptable with such difference in perceptions being statistically significant. This finding too is consistent with that of Clikeman et al. (2000). 
The Impact of Situational and Demographic Factors on Ethical Perceptions of Earnings Management Practices among Professionals

Table 6: Intention of Earnings Manipulation

\begin{tabular}{lcccc}
\hline Manipulation & N & Mean & SD & Mean Difference \\
\hline $\begin{array}{l}\text { Reducing the inventory obsolescence reserve } \\
\text { to facilitate some product development } \\
\text { projects (Scenario 6a) }\end{array}$ & 90 & 2.59 & .982 & $-0.480 * * *$ \\
$\begin{array}{l}\text { Reducing the inventory obsolescence } \\
\text { reserve to facilitate meeting budgeted profit } \\
\text { targets (Scenario 6b) }\end{array}$ & 90 & 3.07 & 1.003 & \\
$*_{p<.10 ; * *}$ ) & & & \\
\end{tabular}

Source: Author's construction

\section{The Impact of Demographic Factors on Perceptions of Earnings Management}

This section presents the t-test and one-way ANOVA results that examine the differences in earnings management perceptions of accounting professionals based on their selected demographic characteristics (i.e., gender, age, sector, employment status, tenure, educational qualifications, and professional qualifications).

\section{Gender}

Table 7 gives the t-test analysis, which examines whether male and female professionals differ in their perceptions of the 13 scenarios. Except for Scenario $2 b$ (the expenses were postponed from November and December until January in order to meet the annual target), there is no statistically significant difference ( $p>.10)$ between male and female professionals in regard to the other scenarios. In Scenario $2 b$, male professionals earned higher scores than female professionals, which is a quite interesting finding.

\section{Table 7: t-Test Results Based on Gender}

\begin{tabular}{llllll}
\hline Manipulation & & N & Mean & SD & Mean Difference \\
\hline $\begin{array}{l}\text { 2b. The expenses were postponed from } \\
\begin{array}{l}\text { November and December until } \\
\text { January in order to meet the annual }\end{array}\end{array}$ & Female & 48 & 3.229 & 0.928 & $0.682^{* * *}$ \\
target. & & & & & \\
\hline
\end{tabular}

$* p<.10 ; * * p<.05 ; * * * p<.01$

Source: Author's construction 


\section{NSBM Journal of Management}

Vol. 1, No. 2, July-December, 2015

Age

The One-way ANOVA analysis done to examine the differences among the four age groups (20-30 years; 31-40 years; 41-50 years; and 51-60 years) selected is presented in Table 8. In Scenarios $2 \mathrm{a}$ (i.e., the expenses were postponed from February and March until April in order to make the first quarter target (Rs. 150,000)), in 4a (i.e., the General Manager [GM] decided to implement a sales programme offering liberal payment terms to secure sales in advance), in 5a (the GM ordered his controller to prepay some expenses and book them in 2013 instead of 2012. (Rs. 60,000)), and in 6a. (the GM ordering the reduction of the reserve for inventory obsolescence to facilitate the continuance of some product development projects that might have been delayed due to budget constraints (Rs. 210,000)), there are statistically significant $(\mathrm{p}<.10)$ differences among the age groups. Further, in general, professionals of the higher age groups have earned higher scores compared to the younger age groups in these scenarios. However, for other scenarios, no statistically significant differences were noted among the age groups of the selected sample.

Table 8: One-way ANOVA Results Based on Age

\begin{tabular}{|c|c|c|c|c|c|}
\hline \multicolumn{2}{|l|}{ Manipulation } & \multirow{2}{*}{$\frac{\mathrm{N}}{65}$} & \multirow{2}{*}{$\frac{\text { Mean }}{2.91}$} & \multirow{2}{*}{$\frac{\text { SD }}{.931}$} & \multirow{2}{*}{$\frac{\text { F-statistic }}{2.853 * *}$} \\
\hline 2a. The expenses were postponed from & $20-30$ years & & & & \\
\hline February and March until April in order & $31-40$ years & 15 & 2.20 & .775 & \\
\hline $\begin{array}{l}\text { to make the first quarter target. (Rs. } \\
150,000 \text { ) }\end{array}$ & $41-50$ years & 6 & 3.00 & 0.000 & \\
\hline & 51-60years & 4 & 3.00 & .816 & \\
\hline \multirow{4}{*}{$\begin{array}{l}\text { The GM decided to implement a sales } \\
\text { programme offering liberal payment } \\
\text { terms to secure sales in advance. }\end{array}$} & $20-30$ years & 65 & 2.74 & 1.094 & $2.613^{*}$ \\
\hline & $31-40$ years & 15 & 3.27 & 1.100 & \\
\hline & $41-50$ years & 6 & 1.83 & .753 & \\
\hline & 51-60years & 4 & 2.75 & .957 & \\
\hline \multirow{4}{*}{$\begin{array}{l}\text { The GM ordered his Controller to prepay } \\
\text { some expenses and book them in } 2013 \\
\text { instead of in 2012. (Rs. 60,000) }\end{array}$} & 20-30 years & 65 & 3.15 & .988 & $5.586^{* * *}$ \\
\hline & $31-40$ years & 15 & 2.20 & .775 & \\
\hline & $41-50$ years & 6 & 3.33 & 1.033 & \\
\hline & 51-60years & 4 & 4.00 & 1.155 & \\
\hline \multirow{4}{*}{$\begin{array}{l}\text { development projects that might have } \\
\text { been delayed due to budget constraints. } \\
\text { (Rs. } 210,000 \text { ) }\end{array}$} & $20-30$ years & 65 & 2.42 & .917 & $2.977 * *$ \\
\hline & $31-40$ years & 15 & 2.93 & 1.100 & \\
\hline & $41-50$ years & 6 & 3.00 & .632 & \\
\hline & 51-60years & 4 & 3.50 & 1.291 & \\
\hline
\end{tabular}

$* p<.10 ; * * p<.05 ; * * * p<.01$

Source: Author's construction 
The Impact of Situational and Demographic Factors on Ethical Perceptions of Earnings Management Practices among Professionals

\section{Industry Sector}

In examining the differences among audit, non-audit and other sectors in respect of the 13 scenarios, the One-way ANOVA results are depicted in Table 9. Except for Scenario 5a (i.e., the GM ordered his Controller to prepay some expenses and book them in 2013 instead of 2012 (Rs. 60,000)) and 7b (i.e., the GM called a consultancy firm partner and asked for a postponement to the next year for sending the payment invoice for the work done this year. (Rs 500,000)), for all other 11 scenarios, no statistically significant ( $p>.10)$ differences among industry sector groups were observed. It is also interesting to note that the in the responses for Scenarios $5 \mathrm{a}$ and $7 \mathrm{~b}$, professionals from audit firms had got higher scores (indicating that the issues are more ethically troubling) than the professionals from non-audit and other sectors.

Table 9: One-way ANOVA Results Based on Industry Sector

\begin{tabular}{|c|c|c|c|c|c|}
\hline Manipulation & & $\mathbf{N}$ & Mean & SD & F-statistic \\
\hline \multirow{3}{*}{$\begin{array}{l}\text { The GM ordered his controller to prepay } \\
\text { some expenses and book them in } 2013 \\
\text { instead of } 2012 \text {. (Rs. } 60,000 \text { ) }\end{array}$} & Audit & 36 & 3.31 & .951 & \multirow[t]{3}{*}{$2.779^{*}$} \\
\hline & Non-Audit & 50 & 2.92 & 1.085 & \\
\hline & Other & 4 & 2.25 & .500 & \\
\hline \multirow[b]{3}{*}{ year on sending the payment invoice for } & Audit & 36 & 4.08 & .692 & \multirow[t]{3}{*}{$6.708 * * *$} \\
\hline & Non-Audit & 50 & 3.52 & .909 & \\
\hline & Other & 4 & 3.00 & 0.000 & \\
\hline
\end{tabular}

${ }^{*} p<.10 ; * * p<.05 ; * * * p<.01$

Source: Author's construction

\section{Employee Status}

The One-way ANOVA analysis done to assess the difference between the different employee levels (top management, middle management, lower management and operational staff) in terms of the 13 scenarios are indicated in Table 10. It is noted that 11 scenarios had no statistically significant ( $p>$.10) difference among these employee levels in terms of the accounting professional perceptions of earnings management, and only Scenario 1 (i.e., advancement of the painting of the headquarters building in 2012 that is due for 2013 (Rs. $150,000)$ ) and $2 b$ (i.e., the expenses were postponed from November and December until January in order to make the annual target (Rs. 150,000)) reveal overall differences. Within these two scenarios, it is quite interesting to note that the operational staff members had obtained higher scores (indicating greater concern for the ethical issues) in comparison to professionals in the top, middle and lower management levels. 
NSBM Journal of Management

Vol. 1, No. 2, July-December, 2015

Table 10: One-way ANOVA Results Based on Employee Status

\begin{tabular}{llllll}
\hline Manipulation & & N & Mean & SD & F-value \\
\hline 1. Advancement of the painting of the & Top Mgt. & 14 & 2.07 & .829 & $2.584^{*}$ \\
$\begin{array}{l}\text { headquarters building in 2012 that } \\
\text { is due for 2013. (Rs. 150,000) }\end{array}$ & Middle Mgt. & 36 & 1.56 & .773 & \\
& Lower Mgt. & 21 & 1.81 & .750 & \\
& Operational staff & 19 & 2.11 & .875 & \\
2b. The expenses were postponed from & Top Mgt. & 14 & 2.71 & .914 & $2.661^{*}$ \\
November and December until & Middle Mgt. & 36 & 3.00 & 1.014 & \\
January in order to make the annual & Lower Mgt. & 21 & 2.48 & 1.289 & \\
target. (Rs. 150,000) & Operational staff & 19 & 3.37 & .895 & \\
\hline
\end{tabular}

${ }^{*} p<.10 ; * * p<.05 ; * * * p<.01$

Source: Author's construction

\section{Tenure}

The fifth demographic factor selected was the tenure and the One-way ANOVA results obtained to examine the differences among the selected tenure ranges in terms of the 13 scenarios are depicted in Table 11. It is observed that Scenarios 5a (i.e., the GM ordered his controller to prepay some expenses and book them in 2013 instead of 2012 (Rs. 60,000)), 6 a (i.e., the GM ordering the reduction of the reserve for inventory obsolesce to facilitate the continuance of some product development projects that might have been delayed due to budget constraints (Rs. 210,000)) and 6b (The GM ordered the reduction of the reserve for inventory obsolescence to facilitate meeting budgeted profit targets (Rs. 210,000)) have statistically significant differences among the tenure categories. However, the other 10 scenarios do not show a statistically significant difference $(\mathrm{p}>.10)$ among the tenure groups concerned. For Scenarios 5a, 6a and 6b, it is generally noted that higher scores (depicting greater concern for the ethical issues presented) were gained by professionals with a longer tenure in their respective organizations. 
The Impact of Situational and Demographic Factors on Ethical Perceptions of Earnings Management Practices among Professionals

Table 11: One-way ANOVA Results Based on Tenure

\begin{tabular}{|c|c|c|c|c|c|c|}
\hline \multicolumn{3}{|c|}{ Manipulation } & \multirow{2}{*}{$\frac{\mathbf{N}}{30}$} & \multirow{2}{*}{$\begin{array}{c}\text { Mean } \\
3.37\end{array}$} & \multirow{2}{*}{$\frac{\text { SD }}{1.033}$} & \multirow{2}{*}{$\frac{\text { F-value }}{0.058 *}$} \\
\hline $5 \mathrm{a}$. & The GM ordered his Controller to prepay & $<=2$ years & & & & \\
\hline & some expenses and book them in 2013 & $3-5$ years & 23 & 2.78 & .795 & \\
\hline & & $6-8$ years & 9 & 2.56 & .527 & \\
\hline & & $9-15$ years & 4 & 2.75 & .957 & \\
\hline & & $>=16$ years & 10 & 3.40 & 1.174 & \\
\hline \multirow[t]{5}{*}{$6 a}$. & \multirow{5}{*}{$\begin{array}{l}\text { The GM ordered the reduction of the } \\
\text { reserve for inventory obsolescence } \\
\text { to facilitate the continuance of some } \\
\text { product development projects that } \\
\text { might have been delayed due to budget } \\
\text { constraints. (Rs. 210,000) }\end{array}$} & $<=2$ years & 30 & 2.40 & .894 & $0.010 * *$ \\
\hline & & $3-5$ years & 23 & 2.30 & .926 & \\
\hline & & $6-8$ years & 9 & 2.78 & .972 & \\
\hline & & $9-15$ years & 4 & 3.50 & 1.291 & \\
\hline & & $>=16$ years & 10 & 3.40 & 1.075 & \\
\hline \multirow[t]{5}{*}{$6 b$. } & \multirow{5}{*}{$\begin{array}{l}\text { The GM ordered the reduction of the } \\
\text { reserve for inventory obsolescence to } \\
\text { facilitate meeting budgeted profit targets. } \\
\text { (Rs. } 210,000 \text { ) }\end{array}$} & $<=2$ years & 30 & 2.77 & .971 & $0.035 * *$ \\
\hline & & $3-5$ years & 23 & 2.87 & .968 & \\
\hline & & 6-8 years & 9 & 2.56 & .882 & \\
\hline & & $9-15$ years & 4 & 4.00 & 1.155 & \\
\hline & & $>=16$ years & 10 & 3.50 & .850 & \\
\hline
\end{tabular}

${ }^{*} p<.10 ; * *_{p}<.05 ; * * * p<.01$

Source: Author's construction

\section{Educational Qualifications}

The differences among the educational qualification categories (General Certificate of Education - Advanced Level, Diploma in Accounting/Finance, First Degree in Accounting/ Finance, Postgraduate Diploma and PhD categories) in terms of the 13 scenarios were tested using the One-way ANOVA analysis and the results are shown in Table 12. The perceptions of earnings management of accounting professionals pertaining to educational categories for Scenarios 2a (i.e., the expenses were postponed from February and March until April in order to make the first quarter target (Rs. 150,000)), 2b (i.e., the expenses were postponed from November and December until January in order to meet the annual target. (Rs. 150,000)), 5 a (the GM ordered his controller to prepay some expenses and book them in 2013 instead of 2012 (Rs. 60,000)) and 7b (The GM called a consultancy firm partner and asked for a postponement to the next year for sending the payment invoice for the work done this year (Rs 500,000)), were noted to be statistically significantly different $(\mathrm{p}<.10)$. However, no clear pattern was observed to indicate that professionals with higher educational qualifications had obtained higher scores. Furthermore, the educational categories for all other 9 scenarios were not found to be statistically significantly different $(\mathrm{p}>\mathrm{.10})$. 
NSBM Journal of Management

Vol. 1, No. 2, July-December, 2015

Table 12: One-way ANOVA Results Based on Educational Qualifications

\begin{tabular}{|c|c|c|c|c|c|}
\hline Manipulation & & $\mathbf{N}$ & Mean & SD & F-value \\
\hline \multirow{5}{*}{$\begin{array}{l}\text { 2a. The expenses were postponed } \\
\text { from February and March } \\
\text { until April in order to make } \\
\text { the first quarter target. (Rs. } \\
150,000 \text { ) }\end{array}$} & GCE A/L & 15 & 2.68 & .488 & \multirow[t]{5}{*}{$2.667 * *$} \\
\hline & Diploma in Acc./Fin. & 16 & 3.00 & .966 & \\
\hline & First degree in Acc./Fin. & 50 & 2.88 & .918 & \\
\hline & Post graduate diploma & 7 & 2.57 & .976 & \\
\hline & $\mathrm{PhD}$ & 2 & 1.00 & 0.000 & \\
\hline \multirow{5}{*}{$\begin{array}{l}\text { 2b. The expenses were postponed } \\
\text { from November and } \\
\text { December until January in } \\
\text { order to make the annual } \\
\text { target (Rs. 150,000) }\end{array}$} & GCE A/L & 15 & 2.87 & .915 & \multirow[t]{5}{*}{$2.139 *$} \\
\hline & Diploma in Acc./Fin. & 16 & 2.75 & 1.065 & \\
\hline & First degree in Acc./Fin. & 50 & 3.08 & 1.104 & \\
\hline & Post graduate diploma & 7 & 2.71 & .951 & \\
\hline & $\mathrm{PhD}$ & 2 & 1.00 & 0.000 & \\
\hline \multirow{5}{*}{$\begin{array}{l}\text { 5a. The GM ordered his controller } \\
\text { to prepay some expenses and } \\
\text { book them in } 2013 \text { instead of } \\
2012 \text { (Rs. } 60,000)\end{array}$} & GCE A/L & 15 & 2.27 & .704 & \multirow[t]{5}{*}{$4.435 * * *$} \\
\hline & Diploma in Acc./Fin. & 16 & 2.88 & .806 & \\
\hline & First degree in Acc./Fin. & 50 & 3.32 & .999 & \\
\hline & Post graduate diploma & 7 & 3.43 & 1.512 & \\
\hline & $\mathrm{PhD}$ & 2 & 2.00 & 0.000 & \\
\hline \multirow{5}{*}{$\begin{array}{l}\text { 7b. The GM called a consultancy } \\
\text { firm partner and asked for } \\
\text { a postponement to the next } \\
\text { year for sending the payment } \\
\text { invoice for the work done this } \\
\text { year (Rs } 500,000 \text { ) }\end{array}$} & GCE A/L & 15 & 3.60 & .507 & \multirow[t]{5}{*}{$3.089 * *$} \\
\hline & Diploma in Acc./Fin. & 16 & 3.19 & 1.223 & \\
\hline & First degree in Acc./Fin. & 50 & 3.96 & .727 & \\
\hline & Post graduate diploma & 7 & 3.43 & .976 & \\
\hline & $\mathrm{PhD}$ & 2 & 4.00 & 0.000 & \\
\hline
\end{tabular}

$* p<.10 ; * * p<.05 ; * * * p<.01$

Source: Authors construction

\section{Professional Qualifications}

The results of the analysis of the differences among different professional qualifications are presented in Table 13. It is observed that professional qualification categories have a statistically significant difference for scenarios $4 \mathrm{c}$ (i.e., the GM sold some excess assets and realized profit of Rs 40,000.) and 7a (i.e., The GM called a consultancy firm partner and asked for a postponement to the next year for sending the payment invoice for the work done this year (Rs 30,000)). Furthermore, no consistent pattern was observed to indicate that professionals with certain professional qualifications had got higher scores for these two scenarios. For the other 11 scenarios, no statistically significant differences $(p>.10)$ were observed among the professional qualification categories. 
The Impact of Situational and Demographic Factors on Ethical Perceptions of Earnings Management Practices among Professionals

Table 13: One-way ANOVA Results Based on Professional Qualifications

\begin{tabular}{llrrrr}
\hline Manipulation & & N & Mean & SD & F-value \\
\hline 4c. The GM sold some excess & No Pro. Qualifications & 1 & 2.00 & & $2.255^{* *}$ \\
assets and realized profit of & CMA & 4 & 1.00 & 0.000 & \\
Rs 40,000. & CA Sri Lanka & 50 & 2.02 & 1.020 & \\
& CIMA & 13 & 1.85 & .801 & \\
& ACCA & 3 & 3.67 & 1.155 & \\
& Banking & 5 & 1.80 & 1.095 & \\
& Multiple Qualifications & 14 & 1.93 & .997 & \\
7a. $\begin{aligned} \text { The GM called a consultancy } \\
\text { firm partner and asked for }\end{aligned}$ & No Pro. Qualifications & 1 & 2.00 & & $2.142^{*}$ \\
a postponement to the next & CMA & 4 & 2.25 & 1.258 & \\
year for sending the payment & CA Sri Lanka & 50 & 2.68 & .957 & \\
$\begin{array}{l}\text { invoice for the work done } \\
\text { this year (Rs 30,000) }\end{array}$ & CIMA & 13 & 2.62 & .506 & \\
& ACCA & 3 & 3.00 & 1.732 & \\
& Banking & 5 & 2.20 & .837 & \\
& Multiple Qualifications & 14 & 3.50 & 1.019 & \\
\hline
\end{tabular}

$*_{p}<.10 ; * *_{p}<.05 ; * * * p<.01$

Source: Author's construction

This section presented the results obtained by performing a t-test and One-way ANOVA analyses, and the next section presents conclusions accompanied with related discussion. ${ }^{1}$

\section{Conclusion}

One of the main concerns raised in the contemporary accounting field is the ethical behavior of professional accountants, and in this backdrop, earnings management has reemerged as an important factor during and after the recent global financial crisis. The intentional manipulation of corporate financial information to achieve an explicit objective is generally considered as earnings management and ethical acceptability could be questionable in most instances. Although different studies had examined the factors impacting on the perceptions of accounting professionals regarding their ethical decisions on managing earnings, the evidence is mixed and not conclusive. Furthermore, the researcher observed a lack of studies done in the Sri Lankan context on this important dimension. Accordingly, the two main

\footnotetext{
1 The non-parametric versions of the independent sample t-test, i.e., the Mann Whitney U-tests and One-way ANOVA analysis, i.e., the Kruskal Wallis tests were performed and qualitatively similar conclusions were noted for the seven demographic factors analyzed under this section.
} 


\section{NSBM Journal of Management}

Vol. 1, No. 2, July-December, 2015

objectives of this study were to examine the impact of situational factors and the impact of demographic characteristics, respectively, on accounting professionals' perceptions of the ethical acceptability of earnings management.

In order to achieve the above research objective, t-tests and One-way ANOVA tests were done to examine the differences between and among the different situational factors and demographic variables in terms of thirteen selected earnings management scenarios, which were adopted from Clikeman et al. (2000). A questionnaire was administered among working accounting professionals and 90 usable questionnaires were secured.

In terms of descriptive statistics pertaining to the 13 scenarios, the highest mean score (indicating the highest ethical concern) was for Scenario $7 \mathrm{~b}$ (work done but not invoiced with the value of Rs. 500,000) of the value of 3.7 (between a minor infraction to serious interaction) while the lowest mean value of 1.91 (i.e., a questionable practice) was observed for Scenario 1 (advancement of a painting job to the current period with the value of Rs. 150,000). In terms of the first objective of this study in examining the situational factors impacting on the accounting professionals' perception of earnings management practices (also indicated under hypothesis H1), when the professionals' perception of accounting manipulations and operating manipulations were considered, it was found that professionals considered that comparatively accounting manipulations to be more serious ethical violations. Further, in terms of the direction of earnings management, the findings indicated that the professionals perceived that increasing current income is more objectionable than reducing current income. On the other hand, where materiality of the particular item was concerned, it was found that the professionals perceived the manipulations involving material items to be a comparatively more serious ethical issue than those involving not so material items. Finally, when the motive of earnings management was considered, it was found that when professionals had good motives, they perceived that it was comparatively ethically more acceptable than other motives. These findings were consistent with the findings of Clikeman et al. (2000) and Merchant and Rockness (1994).

In terms of the second objective of the study, which was to examine the impact of demographic characteristics of accounting professionals on the earnings management practices (also indicated under hypothesis H1), overall, the findings of One-way ANOVA and independent sample t-test results indicated that there was no significant difference in the perception of the ethicality of earnings management based on the professionals' demographic characteristics of gender, age, sector, employment status, tenure, educational qualifications, and professional qualifications. This finding is supported in the extant literature discussed 
before that suggests the absence of definitive evidence of the impact of demographic factors on ethical perceptions of professionals. However, under specific scenarios certain differences were observed. Under gender, for Scenario $2 b$, it is observed that male professionals earned higher scores than female professionals, which is a quite interesting finding. In terms of age, categories under Scenarios 2a, 4a, 5a, and 6a were found to be statistically significantly different, and it was also s noted that higher age groups earned higher scores compared to younger age groups under these scenarios. In the industry sector, groups under Scenarios $5 \mathrm{a}$ and $7 \mathrm{~b}$ were found to be statistically significantly different, and professionals from audit firms had shown higher scores than professionals from non-audit and other sectors. The One-way ANOVA analysis done for employee status showed that employee categories for Scenario 1 and Scenarios $2 b$ had statistically significant differences, and it was noted that operational staff members had earned higher scores in comparison to the professionals in the top, middle and lower management levels. Next, in terms of tenure, the results indicated that tenure categories for Scenarios 5a, 6a, and $6 \mathrm{~b}$ were different on a statistically significant basis, and it was noted that higher scores were obtained by professionals with longer tenure in their respective organizations. Under educational qualifications, Scenarios $2 a, 2 b, 5 a$ and $7 \mathrm{~b}$ were noted to be different among different educational groups, but a clear pattern was not observed to indicate that professionals with higher educational qualifications had earned higher scores. The results for professional qualifications showed that groups for Scenarios $4 \mathrm{c}$ and $7 \mathrm{a}$ were different on a statistically significant basis. However, no consistent pattern was observed to indicate that professionals with certain professional qualifications had higher scores for these two scenarios. Based on these findings, it could be finally concluded that despite having some impact under certain selected scenarios, overall, the demographic factors of the professionals did not have a consistent and systematic impact on the ethical perception of earnings management. These findings shed light on an important topic (i.e., perceptions of earnings management practices) that has not been yet examined adequately in the local context.

\section{Implications and Future Directions}

The findings of this study are expected to have significant policy implications, particularly in terms of academic and professional accounting education and training. The findings relating to the situational factors indicated that Sri Lankan professionals considered operating manipulations to be relatively less unethical than accounting manipulations. However, it should be noted that both are quite unethical, and in certain instances, operating manipulations could have relatively dire consequences on the entity's future. The emphasis placed on accounting education and training is that if accounting standards are followed and complied with (thus avoiding accounting manipulation), there would be no issue, and such 


\section{NSBM Journal of Management}

Vol. 1, No. 2, July-December, 2015

accounting education and training do not emphasize that operating earnings management is indeed equally unethical. Furthermore, academic and professional accounting education and training should emphasize that despite the materiality, intention and direction of unethical practices, any unethical practice should be seen from the same perspective. Accordingly, the findings of this study are expected to provide insights for policy makers into the academic and professional accounting education and training in professional ethics.

For future research, it is suggested that other factors that may influence the ethical perceptions of the professionals in terms of earnings management be used as this study considered only selected situational and demographic factors.

\section{References}

Ahadiat, N \& Hefzi, H 2012, 'An investigation of earnings management practices: examining Generally Accepted Accounting Principles', International Journal of Business and Social Science, vol. 3, no. 14 , pp. 245-251.

Belkaoui, A 2004, Accounting theory, 5th edn, Thompson Learning, Singapore.

Bruns, WJ \& Merchant, KA 1990, 'The dangerous morality of managing earnings', Management Accounting, vol.72, no. 2, pp. 22-25.

Clikeman, P, Geiger, M, \& O'Connell, BT 2000, 'Student perceptions of earnings management: the effects of national origin and gender', Teaching Business Ethics, vol. 5, no. 4, pp. 389-410.

Clikeman, P \& Henning, S 2000, 'The socialization of undergraduate accounting students', Issues in Accounting Education, vol. 15, no. 1, pp. 1-17.

Cohen, J, Pant, LW \& Sharp, DD 1998, 'The effect of gender and academic discipline diversity on the ethical evaluations, ethical intentions and ethical orientation of potential public accounting recruits', Accounting Horizons, vol. 12, no. 3, pp. 250-270.

Copeland, J 2005, 'Ethics as an imperative', Accounting Horizons, vol. 19, no. 1, pp. 35-43.

Deshpande, SP 1997, 'Managers' perception of proper ethical conduct: the effect of sex, age, and level of education', Journal of Business Ethics, vol. 16, no. 1, pp. 79-85.

Eaton, TV \& Giacomino DE 2001, 'An examination of personal values: differences between accounting students and managers and differences between genders', Teaching Business Ethics, vol. 5, no. 2, pp. 213-229.

Elias, R 2002, 'Determinants of earnings management ethics among accountants', Journal of Business Ethics, vol. 40, no. 1, pp. 33-45.

Elias, R 2004, 'The impact of corporate ethical values on perceptions of earnings management', Managerial Auditing Journal, vol. 19, no. 1, pp. 84-98.

Ferrell OC \& Gresham LG 1985, 'A contingency framework for understanding ethical decision-making in marketing', Journal of Marketing, vol. 49, no. 3, pp. 87-96. 
Fischer, M \& Rosenzweig, K 1995, 'Attitudes of students and accounting practitioners concerning the ethical acceptability of earnings management', Journal of Business Ethics, vol. 14, no. 6, pp. 433444 .

Forsyth, D 1982, 'Judging the morality of business practices: the influence of personal moral philosophies', Journal of Business Ethics, vol. 11, no. 5, pp. 461-470.

Geiger, MA \& O'Connell, BT (1999), 'Accounting student ethical perceptions: an analysis of training and gender', Teaching Business Ethics, vol. 2, no. 4, pp. 371-388.

Greenfield, Jr. AC, Norman, CS \& Wier, B 2008, 'The effect of ethical orientation and professional commitment on earnings management behavior', Journal of Business Ethics, vol. 83, no. 3, pp. 419-434.

Healy, PM \& Wahlen, JM 1999, 'A review of the earnings management literature and its implications for standard setting', Accounting Horizons, vol. 13, no. 4, pp. 365-383.

Hunt, S \& Vitell, S 1986, 'A general theory of marketing ethics', Journal of Macromarketing, vol. 6, no. 1, pp. 5-16.

Jooste, L 2011, 'A comparison of ethical perceptions of earnings management practices', SAJEMS NS, vol. 14 , no. 4, pp. 422-434.

Kaplan, S 2001, 'Ethically related judgments by observers of earnings management', Journal of Business Ethics, vol. 32, no. 4, pp.285-298.

Keller, AC, Smith KT, \& Smith LM, 2007, 'Do gender, educational level, religiosity, and work experience affect the ethical decision-making of U.S. accountants?', Critical Perspectives on Accounting, vol. 18, no. 3, pp. 299-314.

Merchant, KA \& Rockness, J 1994, 'The ethics of managing earnings: an empirical investigation', Journal of Accounting and Public Policy, vol. 13, no. 1, pp. 79-94.

Parfet, WU 2000, 'Accounting subjectivity and earnings management: a preparer perspective', Accounting Horizons, vol. 14, no. 4, 481-488.

Rosenzweig, K \& Fischer, M 1994, 'Is managing earnings ethically acceptable?' Management Accounting, vol. 75, no. 9, pp. 31-34.

Sweeney, J 1995, 'The moral expertise of auditors: an exploratory analysis', Research on Accounting Ethics, vol. 1, pp. 213-234.

Wesley, C \& Ndofor, H 2013, 'The great escape: the unaddressed ethical issue of investor responsibility for corporate malfeasance', Business Ethics Quarterly, vol. 23, no. 3, pp. 443-475. 